\title{
The Bakru Speaks
}

\section{Money-Making Demons and Racial Stereotypes in Guyana and Suriname*}

\author{
Rogério Brittes W. Pires \\ Universidade Federal de Minas Gerais, Belo Horizonte, Brazil \\ rogeriobwp@gmail.com
}

Stuart Earle Strange

Yale-NUS College, Singapore

strange@yale-nus.sg.edu

\section{Marcelo Moura Mello}

Universidade Federal da Bahia, Salvador, Brazil

mmmello@gmail.com

\begin{abstract}
Throughout the Guianas, people of all ethnicities fear one particular kind of demonic spirit. Called baccoo in Guyana, bakru in coastal Suriname, and bakulu or bakuu among Saamaka and Ndyuka Maroons in the interior, these demons offer personal wealth in exchange for human life. Based on multisited ethnography in Guyana and Suriname, this paper analyzes converging and diverging conceptions of the "same" spirit among
\end{abstract}

* Most of the research for this article was carried out by the authors during fieldwork for their Ph.D. dissertation. The research was financed by The National Science Foundation, The Social Science Research Council, The Wenner Gren Foundation, and the University of Michigan's Department of Anthropology (Stuart Strange); by Conselho Nacional de Desenvolvimento Científico e Tecnológico (CNPq) and Museu Nacional's Graduate Program in Social Anthropology, Universidade Federal do Rio de Janeiro (UFRJ) (Marcelo Mello and Rogério Pires); and by a CNPq postdoctoral scholarship in the Universidade Federal de Minas Gerais (Rogério Pires). Previous versions of this article were presented twice in 2015 and once in 2017: in a seminar at Museu Nacional/UFRJ, in a panel session at the American Anthropological Association (AAA) meeting, and in a lecture at Universidade Federal de Juiz de Fora (UFJF). Comments by John Willems, Olívia M.G. da Cunha, Diana Paton, Robert W. Slenes, Alexandre Marcussi, André Dumans Guedes, Luiz Felipe Benites, Carlos Gomes de Castro, and Indira Viana Caballero were useful in refining our ideas.

(C) ROGÉRio brittes W. Pires, StUART EARLE STRANGE AND MARCELO MOURA MELLO, 2018 | DOI: 10.1163/22134360-09201001

This is an open access article distributed under the terms of the prevailing CC-BY-NC license at the time of publication. 
several Afro- and Indo-Guianese populations. We argue that transformations in how people conceptualize bakulu reveal how supposedly radical moral differences are constructed within and between populations in the multi-ethnic Caribbean. More than figurative projections of monetized inequality or racial and ethnic prejudices, baccoo actively mediate how people throughout the Guianas think about and experience the everyday conduct of economic and racial relations.

\section{Keywords}

Suriname - Guyana - spirits - money - capitalism - ethnic difference

Take any Maroon village in the interior of Suriname and it probably has a story like this: a man starts a business, maybe a tourist camp or a shop, and becomes prosperous. ${ }^{1}$ While elsewhere he might be viewed as an astute entrepreneur, in today's Suriname, wealth brings mistrust - especially accusations that his success has been illicitly acquired through a blood contract with a moneymaking bakuu demon. Not all successful businessmen are accused of being bakuu owners, however. Financial acumen is suspicious only to the (perhaps inevitable) degree it changes a person's character. Maybe the man refuses to share with kin and friends. He avoids others even as he enlarges his house and surrounds himself with luxury commodities. Shut in his home or away in the city, rumors spread but remain indefinite. One day, members of his family begin to be caught by a series of problems: miscarriages, diseases, and deaths. Different oracles are consulted to determine the reason for each misfortune, but the results are ambiguous. In the etiological breach, someone mentions "a short thing" (bakuu), but it is only a suspicion on which no one acts.

One night the businessman's adolescent granddaughter wakes in a frenzy, smashes the furniture in her house, and attempts to gouge the eyes of those

1 There are six Maroon groups in Suriname and French Guiana: Saamaka, Ndyuka (or Okanisi), Aluku (or Boni), Matawai, Pamaka, and Kwinti. They are usually grouped together in contrast with Creoles - rural and urban African Surinamese who are not descendants of runaway slaves. In their own languages, they collectively call themselves Businenge or Busisama, literally "Bush Negroes" - an expression that sounds derogatory in English and Dutch (bosnegers), but which the Maroons we know seem very comfortable with. The term Djuka, a corrupted version of Ndyuka, used by coastal Surinamese and Guyanese to indiscriminately refer to all six peoples, is considered highly derogatory but widely used. 
fighting to restrain her. Struggling against her uncanny strength, neighbors manage to get her out of the house and pin her to a chair. Publically exposed, the girl's fury becomes a village affair. Over the next few days the girl is unwillingly kept outdoors as her fellow villagers seek the appropriate treatment. She is clearly possessed; the spirit confesses to being a bakuu, and publicly accuses "someone in the lineage" of buying it in the city to extract wealth in the village. The businessman is never actually named, but in private conversations people are increasingly sure of the culprit's identity. The case is strong: not only does the businessman's behavior and genealogical position within his kin group match what is known about bakuu buyers, he was one of a very few villagers to avoid the spectacle of his own granddaughter's possession-an absence that indicates fear of direct accusation by the enraged bakuu.

During the girl's ordeal, before being temporarily freed from the spirit "screaming in her head," the normally reticent villagers talk openly about the origins of bakuu. People recount stories they have heard about how bakuu behave, what they eat, their relationships to other forms of spirit and sorcery, the rich people in the city who supposedly own them, and the best means of exorcism. Everyone agrees they are purchased in urban areas on the coast, but wonder whether their true beginnings are further afield in India, Afghanistan, or elsewhere. In Maroon villages, bakuu are invariably linked to people of South Asian descent (akuli, kuli), whom Maroons regard as the wealthiest and most prejudiced of Suriname's many ethnic groups. ${ }^{2}$

Long after the girl's possession abates, problems in the businessman's matrilineage continue to be attributed to "his" bakuu. Other young kinswomen are similarly seized by it, and male relations have unsettling dreams of a stranger

2 Descendants of people brought to the Caribbean as indentured workers between 1838 and 1917. In Suriname, they are most commonly referred to as "Hindustani" (Dutch: Hindostanen) whether or not they are Hindu or have origins in Hindi-speaking regions and an earlier synonym is "British Indian" (Brits-Indiërs), since they were brought from British colonies in Asia. In Guyana, they are commonly referred to as "Indians." In trying to find a way to refer to these populations that is both somewhat consistent with local usages and not confusing to the reader, we have come across a few problems: "Indo-Guyanese" and "East Indians" could apply to the Guyanese, but in Suriname the presence of a large Surinamese-Javanese population confuses the matter. Simply "Indians," however, would be confusing given there are Amerindian populations in both countries. Our choice, then, is to use "Hindustani" for Surinamese people with ancestry on the Indian subcontinent, "Indo-Guyanese" for Guyanese people of the same descent, and "South Asian" as a general term (even if it is a tad academicist). We will avoid derogatory labels such coolie (English, Creolese) or kuli or akuli (Sranan, Saamakatongo), except in quotations. 
who presses them to buy dolls or babies that nearly everyone interprets as attempts by the bakuu's owner to get rid of it by passing it onto unsuspecting lineage members. Increasingly pervasive, such suspicions provoke the accused to redistribute a portion of his money, temporarily shutter his business, and refrain from boasting of his financial success in the hope of avoiding further shunning and animosity.

We have told this story in vague terms, pieced together from numerous incidents about which we have been told and episodes we have witnessed directly. Drawing on multiple strands of evidence, in this article we argue that struggles with mercenary bakuu demons critically mediate how people across the Guianas use money and conceptualize wealth. Whether called bakru, baccoo, bakulu or bakuu, in this article we describe the ways in which these malicious spirits cross national, ethnic, and religious borders, and what it is about them that exacerbates the general sense that wealth is frequently only available at the expense of moral relationships. ${ }^{3}$ Maintaining a parallel focus on Ndyuka/Saamaka Maroons and Indo-Guyanese/Hindustani populations that imagine themselves as occupying irreconcilable poles on Suriname and Guyana's ethnic spectrums, we suggest that the very fact that bakuu so readily cross these particular ethnic and national boundaries illustrates something critical about their social power. ${ }^{4}$

Though ideas about bakuu frequently conflict, there is convergence on several important points. Even within a small community like the village in the story just recounted, descriptions of bakulu are both fairly consistent and uniquely open to doubt when compared with more established spirits and deities. Because bakru are habitually perceived as foreign deceivers, they are never wholly knowable. When these demons act within a community, the attendant conversations simultaneously concern the social relations that instigated that particular baccoo's depredations, and speculation about this type of spirit's ultimate source. As witnessed in our opening story, two levels of gossip circulate about bakuu, the first embedded in the everyday material conditions

3 Baccoo, bacoo or baku is the Guyanese Creole (Creolese) version; bakulu is Saamakan (Saamakatongo); bakru is Surinamese Creole (Sranantongo); and bakuu is Ndyuka/Aukaner (Ndyukatongo/Okanisi). As we describe the transformations of the spirit so designated across communal and national borders, we use all of these names interchangeably.

4 We refer to Kuiperbak's (1989) and Jolivet's (2013) articles about bakroes and baklous among Afro-Surinamese and Guianese Creoles in the Netherlands and French Guiana that would add complexity to our argument but which, due to space constraints, cannot be adequately incorporated into the present analysis. 
and social conflicts in which the businessman made his money; the second, in more abstract theories about the weaponization of local greed by destructive ethnic others.

Through routine accusations of bakru distribution, ethnic others are inculpated in local suffering. In this way, denunciations involving bakulu communicate something critical about the construction of supposedly radical moral differences both between and within populations in multiethnic societies. Such mutually reinforcing interethnic accusations make bakuu demons a common index of greed and its social consequences. As "levelers" of traditional values that eat through relations of trust like a caustic "acid," baccoo are imbued with many of the characteristics of money attested by the classic social theories of Marx (1976) and Simmel (2004), among others. Because most of our interlocutors understand money as a challengingly foreign substance (Pires 2017), bakru and money share occult qualities that comparably confound easy explanations of how they work. In this way, gaps in people's knowledge about what money and bakuu really do invite speculations that concurrently testify to their power and insulate their systematic questioning. This throws up an epistemic chiaroscuro that invites people to fill in gaps in their knowledge with shreds and patches of information they feel certain of, further extending the uncanny power of demonic and monetary mediation.

This compliments a correlation found throughout the ethnographic literature between fears about commercially traded spirits and the introduction of money into nonmonetary economies. Wherever capital or the state penetrate, "occult economies" (Comaroff \& Comaroff 1999) that swarm with correspondingly vicious spirits seemingly spring up. Most anthropological work on the sorcerous worlds that appear to shadow global capital everywhere approach the spirits who populate them as phantasmagoric metaphors, tropic witnesses that "mirror" the traumas of social inequality and institutional violence. Though duly acknowledging the analytic power of these approaches, we contend that the consequences of bakuu exceed mere figurative projections of money or racial and ethnic tensions. Our central argument is that bakuu surpass simple reflections of political economy to actively mediate how people throughout the Guianas think about social relations when they conduct the economic aspects of their lives.

As defined by Bruno Latour, mediators have "the capacity to translate what they transport, to redefine it, redeploy it, and also to betray it." Unlike intermediaries, which can establish links but "lack any ontological status" themselves (Latour 1993:8o-81), mediators actively change the connections that make up a network of relations. Previous scholars have interpreted bakuu and other denizens of occult economies as intermediaries that render the "real" forces 
of capital and colonial oppression into local "symbols." Analyzing baccoo as mediators enables us to extend the insights of symbolic approaches while placing local concepts on a par with the abstractions of Euro-American theory.

Discursive objects that can only be inferred from their effects, capitalism and colonialism are no less visible to most of humanity than bakuu. Just as capitalism is best understood as simultaneously a historically contingent aggregate of diverse ideas and practices that nevertheless radically reshape reality, we contend that approaching bakru through what Guianese people see as their everyday effects permits better appreciation of the processes by which agencies like spirits and money come to dominate social life. Because Guianese people across ethnic groups perceive bakulu through money, and money through bakulu, these spirits exercise a vital influence on how people conceive of what money is, how it should be used, and the ways in which it defines intra- and interethnic trust. Accordingly, we want to follow our interlocutors' reflective experience of postcolonial capitalism where baccoo are one of the many real problems people must confront. ${ }^{5}$

\section{Crossing Borders}

In 2012, all three of us were conducting fieldwork in Guyana and Suriname: Marcelo Mello at the Blairmont Kali Temple in Berbice, Guyana; Rogério Pires in the Saamaka village of Botopasi in Suriname; and Stuart Strange with urban Ndyuka Maroons and Indo-Guyanese and Surinamese Hindus in Paramaribo. During this time, Marcelo invited Rogério to visit him at his fieldsite for a Hindu festival, the Big Puja. Members of both communities reacted to these plans with often-derogatory ethnic and national stereotypes of a kind immediately recognizable to Stuart from his experience living between Maroon and Hindu communities in Paramaribo.

Saamaka people warned Rogério to be extra careful in Guyana, a country they imagined as poor and violent, "full of thieves" and "like a ghetto." Negative views of Guyana are common among Surinamese of all ethnic backgrounds, the result of the tens of thousands of Guyanese who have left the former British colony over the past decades to settle in Suriname or use it as a stepping stone to migrate to other countries. Many Guyanese immigrants to Suriname end up unemployed or underemployed at the margins of society,

5 See Palmié (2006) for a similar approach in a different context. 
and Surinamese - even members of otherwise marginalized populations like Maroons-frequently treat Guyanese with contempt.

Marcelo's interlocutors at the Blairmont Kali temple were equally apprehensive about Rogério — the odd white Brazilian living with "Djuka" (the pejorative term Guyanese use to refer to all Surinamese Maroons). Similarly to Maroon stereotypes about South Asians, in Guyana Djukas are considered very dangerous due to their skill at obeah-understood as black magic or witchcraft. ${ }^{6}$ Though the suggestion was later discarded for reasons unknown to us, some members of the Hindu temple even suggested that Rogério be ritually cleansed before being allowed in the temple. Despite their anxieties, Indo-Guyanese people were genuinely curious about Maroons. They wanted to know if it was true that if Djuka felt offended they could instantaneously kill those they felt offended them with black magic. They also inquired if it was true that Maroons had enormous heads and that women dragged their perpetually bare breasts along the ground. But mostly they demanded to hear about baccoo. When Rogério finally admitted that he did not know where to buy or how to properly feed a baccoo, he was chided for not doing his fieldwork properly. "Aren't you studying their culture? What are you doing there if you don't know that stuff?," said one young man visiting from New York to attend the temple's annual Puja.

As is the case with spirits in many parts of the world, in Guyana baccoo are simultaneously a widely attested topic of definite knowledge and an elusive mystery obscured by the half-light of rumor. ${ }^{7}$ Guyanese from all ethnic groups routinely told Marcelo that baccoo are exclusively purchased in Suriname, where Djukas capture them in the jungle for sale to greedy and unscrupulous members of other ethnicities. Once purchased, the simple requirement that a baccoo's owner keeps it hidden and fed with a steady supply of milk and bananas quickly escalates. Even the most cautious owner must eventually be overcome by their baccoo's insatiable demands. ${ }^{8}$ While an owner's care might

6 According to Bilby \& Handler (2004:154): "Although the specific beliefs and practices embraced by this term [obeah] varied from place to place, obeah everywhere [in the Caribbean] shared at least two fundamental characteristics: (1) its practice involved the manipulation and control of supernatural forces, usually through the use of material objects and recitation of spells; and (2) it was primarily concerned with divination, healing and bringing good fortune, and protection from harm —although it was sometimes used malevolently to harm others."

7 See Mello 2014 and, for similar cases globally, Akin 1996, Bubandt 2014, Geschiere 1997, Keane 1997, and Taussig 1980.

8 Most of Marcelo's interlocutors, both Indo- and Afro-Guyanese, agree about these matters. Only once, in a brief conversation in Georgetown, did two Afro-Guyanese women voice a 


\section{THE BACCOO SPEAKS \\ The Christmas season is upon us and with it should be peace and joy. Instead, there is a lot of anger in some quarters. A family is going to be warring all month and that war is going to climax in bloodshed. Police ranks who would.expect to have a quiet time will be busy. \\ The streets will be full of people, some of whom will be out to make their families happy, but there will be those who will be out to make themselves happy. These are some of the people who would be spending the holidays in custody. But not before they bring tears to the.

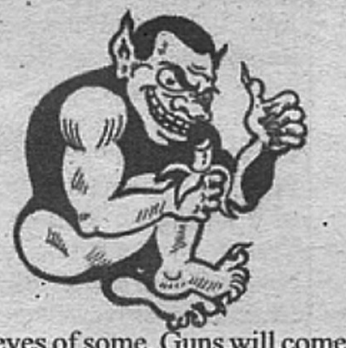 \\ eyes of some. Guns will.come out and blood will flow. \\ **** \\ A drowning will rock a family. A young boy is going to go for a swim with friends. Although adults will be around no one will miss him until it is too late: \\ With the kind of weather that is going to prevail there will be another fire. Of course there will be the accusation of arson but in fact, carelessness will be the order of the day. \\ Decorations and all will go up in flames because sleep will take precedence over cooking. Things that should be done during the daylight hours must not be attempted late at nights. \\ ***** \\ An unnecessary investigation is underway because someone is worried that the person being investigated knows too much.}

FIGURE 1 “The Baccoo Speaks,” Kaieteur News, December 18, 2011

be repaid with short-term financial success, the baccoo's devouring needs will inevitably result in the death of one or more of their close family members or friends.

The baccoo as "public secret" is enacted every Sunday in "The Baccoo Speaks" column of Kaieteur News, one of Guyana's major newspapers. This mass media baccoo is a cartoonish character of black humor that makes ironic predictions about future tragedies such as accidents, murders, and violent disputes to indict the perceived impossibility of Guyanese people to ever live peacefully with one another.

The effectiveness of the newspaper baccoo's moralizing ridicule derives from the pointed uncertainty of rumors in Guyanese life. Most Guyanese only know baccoo through gossip (talkname) that is frequently construed as character assassination. Common Guyanese concerns with reconciling a widely held egalitarian ethos with personal success under conditions of pronounced inequality (Williams 1991) permit baccoo to inhabit the controversies created by

very different view: they said that the baccoo can be found in gold mining spots, where they may take the shape of a man in order to have sex with women, bringing them unhappiness and sickness. 
social inequity. Generally speaking, successful businessmen who never seem to suffer material losses are said to be baccoo owners, as are those who become unexpectedly rich. Both Marcelo's and Stuart's Guyanese informants said that, though concealed, baccoo are apparent in the sudden construction of a fancy home or the unexpected acquisition of a new car.

Among Marcelo's informants, only ritual healers (obeah-men) and priests of the Hindu goddess Kali (pujaries) are considered able to deal with baccoo. Drawn together by shared history, healers from both Indo- and Afro-Guyanese traditions use their alliances with deities and spirits to discipline and expel malignant baccoo that take possession of people's bodies and lands. Guyanese in Suriname told Stuart that the landscape of both countries is infested with the delinquent power of abandoned baccoo. Though their major ravages consist in preying on their owners' unsuspecting family, abandoned baccoo make a property's subsequent dwellers sick and steal valuables such as gold jewelry.

In direct opposition to Indo-Guyanese stereotypes, in Suriname, Saamaka and other Maroons unanimously see bakuu as kuli (i.e., "South Asian") spirits. Bakulu are understood as the preeminent occult means used by the "Hindustani" to achieve their proportionally greater wealth. Saamaka rumor claims that Hindustani people sacrifice newborns to bakulu, and many Ndyuka allege that bakuu are the corrupted spirits of dead infants. Maroons commonly accuse shopkeepers of South Asian descent in Paramaribo of selling bakulu. Filled with contempt for Afro-Surinamese, and eager to be rid of their own persecuting spirits, these shopkeepers unload bakulu on to Maroons unscrupulous or malevolent enough to sacrifice their kin in the pursuit of personal wealth. Just as for Indo-Guyanese, Maroons regard bakulu's demands as insatiably consuming their owner's family. As with the much-feared avenging spirits (kunu) that decisively influence Maroon life, bakulu mainly target their owners' matrilineal kin with misfortune, accidents, diseases, and death. Bakulu are different from kunu, however, because they are likely to afflict people beyond the owner's matrikin, like husbands and wives (Price 1973; Pires 2015). In this respect, bakuu are closely tied to Maroon ideas about witchcraft - particularly for Ndyuka for whom bakuu have become synonymous with assault magic to the extent of rendering earlier methods obsolete. ${ }^{9}$

9 The Saamaka do not equate assault magic with bakulu as readily as do Ndyuka. Both the ethnographic literature and our own fieldwork shows that, when comparing Saamakas and Ndyukas, the latter place greater emphasis on policing sorcery like bakuu. We do not have enough contemporary information on other Maroon groups to provide a comparison about the impact of bakuu on their ritual and economic life. While Rogério's fieldwork was mostly conducted among Christian Saamakas, people from non-Christian Saamaka villages in Upper 


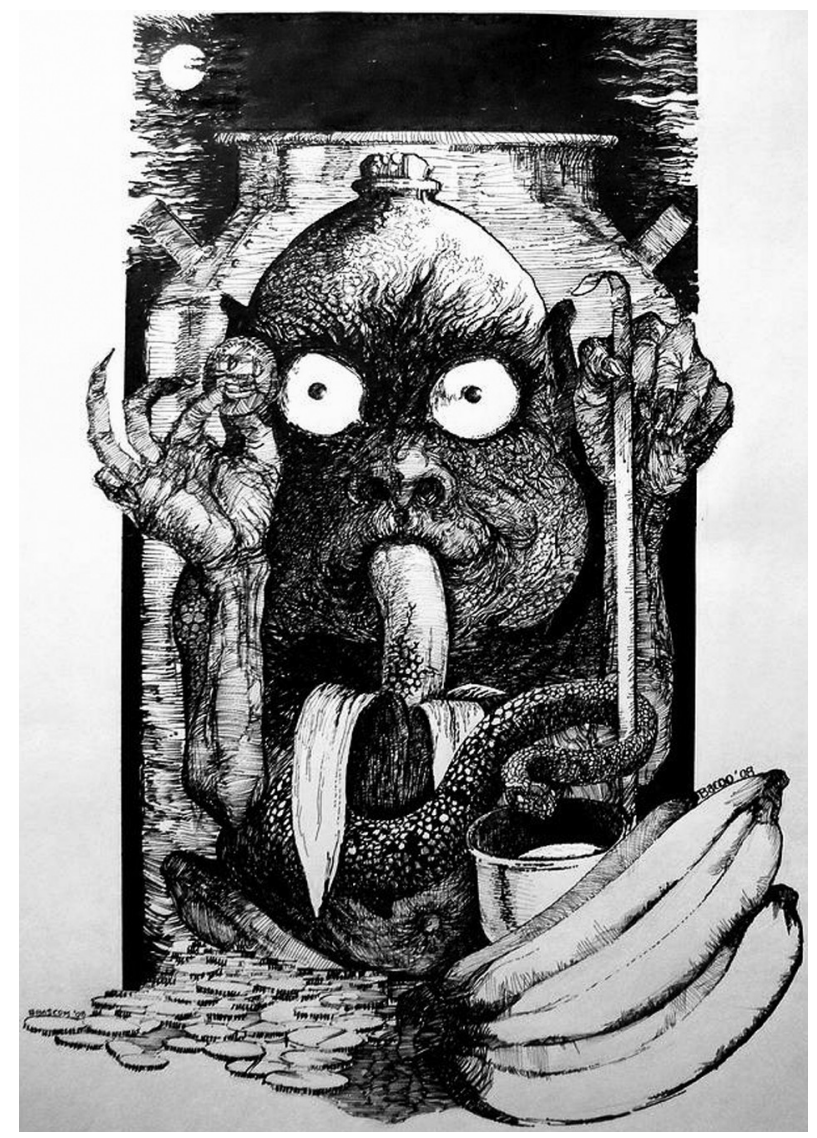

FIGURE 2 "Baccoo," by Harold Bascom (pen and ink drawings from the "Guyana Gothic Series"), (C) 2012

Although statements about these demons by the Saamaka and Ndyuka whom Rogério and Stuart lived with were fragmentary, and controversial in respect to certain details, there was enough agreement to extrapolate a general Maroon theory of bakuu as powerfully deceptive demons. Bakulu are often bought in pairs and reproduce epidemically within their buyer's community. To move quickly from place to place, bakuu ride cats as if they were horses. They appear in dreams, assuming the form of babies or dolls to trick the dreamer

Suriname also frequently mentioned bakuu, and word of collective possessions by bakulu hordes in "traditional" villages freely circulated around the river (see note 13). The best available ethnography on Saamaka obia techniques however, Price's Travels with Tooy (2008), makes only passing mentions of bakulu. 
into buying them. Because bakulu's desires always exceed human ability to satisfy them, even the killing of their owners' kin is insufficient to satiate them. To voice their grievances, bakuu possess members of their owners' families, especially young women. Speaking in coarse Sranan (the lingua franca of Suriname's markets and streets), bakulu mediums demand offerings in recompense for their inevitable ill treatment. Different from other Saamaka possessing spirits, a single bakuu can have several mediums: in Saamaka and Ndyuka villages, people claim that up to twelve girls may be possessed at once by a single bakulu (or a legion of bakuu). A person possessed by bakuu acts violently, attacking people and breaking and burning property, between fits of hysterical laughter, squirming, and swearing.

As is the case with other possessing spirits, Saamaka and Ndyuka frequently consult mediumistic healers (obiama/obiyaman) to exorcize bakuu. These mediums use the power of their own possessing spirits to subjugate bakulu, either driving them out of the sufferer's body or, in a method derived from coastal Afro-Surinamese Creoles, domesticating them into a medium's stable of possessing spirits. Maroons see medium-spirit relationships as entailing symbioses between spirit and host. However, being so dangerous, the "domestication" of a bakuu is considerably less frequent than for deities related to large felines and vultures (komati), constrictor snakes (papa gadu, watawenu) or bush spirits (apuku) (cf. Price 2008:427, note 5). Though some say bakulu are beyond taming, others hold that problems with bakuu are the fault of human nature: "Bakuu don't kill people, people kill people," one urban Ndyuka bakuu medium told Stuart. Whatever the ultimate solution, bakulu can only ever be temporarily tamed or exorcized. Given the threat bakulu pose to the elementary relations of Maroon social life and the reputations of their unscrupulous buyers, bakulu owners are held to try and evade responsibility by conning others into accepting their bakulu through the gift of a box or bottle. Freely accepting such poisoned presents transfers ownership to the receiver and all related to them. We should add that it is common to suspect people of converting to Christianity in an attempt to avoid bakuu liabilities, further yoking the bakuu's owner's unsuspecting traditionalist family with the results of their malice (cf. Richman 2005 for Haiti).

Bakulu were the most common kind of possessing spirit during Rogério's fieldwork in Botopasi, a historically Moravian village. Commonly described as "devils" (didibi), bakulu accord with Christian Saamaka cosmology and, in parallel to Guyanese baccoo conceptions, enact contradictions between ideals of kin-based material equality and aspirations for personal success exasperated by desire for "development." Throughout Upper Suriname, economically successful men are the most likely to be accused of owning bakulu. No one 
wants to be poor, so money is imagined as universally desired. At the same time, as the source of inequality, money is accounted as the origin of greed and collective suffering- "money is the devil," runs a common Maroon saying.

In Botopasi, some assert that to use even the most benevolent sorts of magic to achieve personal wealth is immoral. One comparatively rich man even said, "Obia for money is work" - meaning that, instead of wasting time using esoteric means to get rich, one should simply work hard to earn it. Other Saamaka do not see acquisitive magic as a problem: if magical medicine strengthens the body, increases the productivity of gardens (taanga sinkii obia), or enables success in hunting (hondi obia), why would it not be reasonable to use obia in acquiring money? Shopping for food, after all, can be called "hunting with money" (hondi ku moni). The inevitably usurious and destructive nature of bakulu is a different matter. The willingness to cut a deal with a bakulu exposes a person as an essentially malignant witch (wisima/wisiman) willing to exchange their lineage's collective future for short-term personal gratification.

\section{Theories of Bakuu}

Despite the public role of baccoo in Guyanese popular culture, the most detailed anthropological accounts of these spirits are from the ethnography of Surinamese Maroons and especially the Ndyuka. ${ }^{10}$ Authors such as Herskovits and Herskovits (1936), and Wooding (1972, 1981) sought the origins of bakru in survivals of widely attested West African "little people" spirits such as the Akan mmoatia. Vernon suggests two parallel pedigrees for the Afro-Surinamese bakuu: an eighteenth-century dwarf bush spirit that could be used for witchcraft, and a malevolent nineteenth-century "puppet" assembled to make money and guard fortunes (Vernon 1985:28-29). These would have become amalgamated during the Lawa gold rush of the late nineteenth century when West

10 Most likely this is because Maroon cosmologies have been more widely and intensively studied than coastal Surinamese, not because the bakuu is more characteristically Maroon. Herskovits \& Herskovits (1936) and Wooding (1972, 1981) and Van Wetering (1989) write about the Afro-Surinamese Creole bakru. For Maroons, aside from the work of Vernon, Thoden van Velzen, and Van Wetering, bakulu are mentioned by Givens (1984) for the Aluku; Lenoir (1973) for the Pamaka; Green (1974, 1978) and De Beet \& Sterman (1981) for the Matawai; Price (2008) for the Saamaka; and Van Lier (1940) and Parris (2011) for the Ndyuka. 
Indian workers sought fortunes in the Maroon-inhabited rainforests on the border between Suriname and French Guyana. For our purposes, we will not recapitulate a genealogy like that so dexterously handled by Vernon, nor attempt to locate the bakuu's ultimate source, but rather explore the implications of the differences and continuities that define contemporary bakuu discourses and practices. Still, it is important to note that the literature on the presentday Guianas agrees that, in whatever form, such commercially traded spirits are imagined as a "Surinamese thing."

What is most striking about bakuu in the ethnographic literature is the consistent variability of their description. Transformations occur in almost every aspect of their depiction, from their supposed ethnic origins, to their relations with other categories of deities and spirits. Sometimes bakru look like Maroon children, or assume the shape of a doll or puppet dressed in Creole clothes. In some places bakru are coal-black, hirsute dwarves. In others, they are composites of wood, flesh, and bone, or enslaved infant ghosts; they can morph into fowls, or assume the guise of a living person. They reside in the city or in the forest. They ride cats or live in statues of Hindu deities. They are completely invisible or are regularly obliquely glimpsed; some say they can be disciplined, others that they are beyond control. They manifest in dreams as gluttonous suckling babies and are heard gobbling bananas in a neighbor's ostentatious new home. They possess people, houses, and land, or are free agents tied only to impossible economies of debt and exchange. Despite this phantasmagorical kaleidoscope of features, a few characteristics remain constant: short stature, greed, duplicity and, most importantly, their being intentionally used as an immoral means of achieving socially corrosive wealth.

However conflicting, the bakru's eating habits are a detail of shared concern across all accounts. We have heard or read of milk and bananas; eggs; sweets and sugar; tea, bread, and other industrialized "city foods;" as well as coins, human flesh, blood, and newborn children. These divergences frame the reciprocity of the accusations that unite different ethnic groups in mutual mistrust. One Saamaka man laughed at Rogério when he told him that Guyanese

11 Gibson (2001:29), writing about baccoo in Guyana, agrees that they are described as coming from Suriname. According to Brent Crosson (2015) and Alex Rocklin (2015), Trinbagoans attest to a further transformation of this spirit. Called buck, they attribute its arrival to Guyanese migrants. It is also described as bringing riches to its owners, who keep it in a shoebox and feed it with milk and bananas. Lewis (1990:90-91) similarly mentions that people in Barbados say bacoos were imported into their country by Guyanese migrants. 
asserted bakulu were of Maroon origin and fed on milk and bananas: "Those things are not from here. They eat tea and bread, or something like that!"

The insistence that the bakuu are foreign to those they afflict is perhaps the most important consistency maintained across their regional proliferation. Whatever knowledge is claimed about them comes with an implicit denial of familiarity. Whoever knows bakulu does so as an attribute of an ethnic other stereotypically beyond ethical assimilation into the community of the person describing them. Whatever the differences, the idiosyncratic dietary needs of baccoo routinely condense their alienness. Commensality and eating habits are a central aspect of relatedness everywhere; "what we eat" helps derive "who we eat with" and a fortiori "who we do not eat with." Ethnic stereotypes are often construed and constructed by perceived differences in culinary habits. No wonder "melting pot" metaphors are so present in Caribbean "plural societies" (Khan 2004; Palmié 2013).

Of the scholars concerned with bakuu, Diane Vernon, H.U.E. Thoden van Velzen, and Wilhelmina van Wetering have provided the most insightful accounts. All did fieldwork with the Tapanahoni Ndyuka and - aside from a few minor disagreements about theoretical preferences and ethnographic focustheir writings converge on interpreting bakuu as a phantasmagoric symbol of the social ambivalences of Ndyuka economic history. The writings of Vernon, Thoden van Velzen, and Van Wetering are exemplary for the depth and subtlety of their ethnographic engagement with Ndyukas' own sense of their history. Our purpose here is not to dispute their conclusions, but to further enrich them in relation to the promiscuous border crossing of contemporary bakuu.

For Vernon, the complexity of Ndyuka "bakuu symbolism" provides a "commentary on changing Ndyuka society" (Vernon 1985:1). Shifts in this symbolism since the early twentieth century mirror changes in Ndyuka participation in the coastal Surinamese economy and its entanglements with global colonial and (post)colonial capitalism. Since the late nineteenth-century gold rush, bakuu have metamorphosed from spirits used by rich European miners to guard their gold claims to wealth-generating witch familiars bought on the coast by greedy Ndyukas. According to Vernon, these shifting portrayals all focus on bakuu as a metaphor for Ndyuka ambivalence toward the source of money among nonMaroons (Vernon 1985:5). Vernon's argument that bakuu are "symbolic containers" for Ndyuka economic anxieties depends on their peripheral position in Ndyuka cosmology. Even compared to other varieties of wealth magic such as pacts with the autochthonous papa (serpent spirits who control underground mineral wealth), bakuu resist assimilation as anything other than a threat. This marginality derives from their essential foreignness to the Ndyuka socius (Vernon 1980:31). 
Vernon claims that bakuu act as symbols of the threat posed to the matrilineal structure of Ndyuka society by dependence on outside wealth and fear of assimilative subordination brought about by foreign penetration into Ndyuka territory. Bakuu would then comprise a flexible "image" of Ndyuka society's sensitivity to their ever-evolving entanglement in global economic processes. Since the late nineteenth century, outside influences have compelled Ndyuka to continually seek new sources of income in logging, river transportation, gold mining, rubber tapping, wage labor on the coast, and small-scale commerce. Each new activity redefined who in Ndyuka society had access to massproduced commodities. The result has been a fluctuating balance of power between ages and genders that destabilized seemingly settled expectations of cooperation and dissent. As new justifications emerge from these shifts in social status, new forms of bakuu proliferate. This explains why, as the primary source of Ndyuka monetary access shifted from European prospectors to Chinese and Hindustani businessmen, the ethnic associations of bakuu altered accordingly.

In parallel to Vernon, Thoden van Velzen and Van Wetering argue that bakuu act as symbols for economic and social transformations in Ndyuka society. ${ }^{12}$ Across a number of innovative books and articles, Thoden van Velzen and Van Wetering have shown that Ndyuka society has repeatedly attempted to confront the moral disruption of major economic changes through successive campaigns of witchcraft eradication. This history has resulted in a distinctively Ndyuka concern with political and cultic centralization that, since the last quarter of the twentieth century, has had bakuu and their dangers as a preponderant fixation.

Uniting Marxist economics and Freudian psychoanalysis, Thoden van Velzen and Van Wetering describe bakuu as "fetishes" and "collective fantasies." Their reading of the bakuu is a particularly iconic instance of a wider materialist analysis of Ndyuka ritual life as a psychosocial response to unstable economic conditions. For Thoden van Velzen and Van Wetering, conceptions of bakuu comprise an emotional answer to the social uncertainties created by resented dependence on the coastal economy and state (Thoden van Velzen \& Van Wetering 2001:20-21). New economic opportunities that combine great risks and high profits tempt aspirant Ndyuka to break the moral bonds of kinship through which Ndyuka organize social life. Bakuu are "collective fantasies

12 Thoden van Velzen 199o; Thoden van Velzen and Van Wetering 2001, 2004, forthcoming; and Van Wetering 1992. 
of evil" that enable Ndyuka "to move from the outer to the inner world, to commute from the economic and political arena to the individual, psychic field of tensions. The occult discourses bridge the gap between the social field and the individual psyche" (Thoden van Velzen \& Van Wetering 20o1:37). Collective projections of the psychic ills generated by these anxieties, bakuu fantasies are not mere fancy. Via the mechanisms of the Freudian unconscious, the apparent absurdity of the manifest content of Ndyuka demon beliefs exposes the latent Marxist materiality of social relations.

The insight gained from Thoden van Velzen and Van Wetering's approach is clearest in a 2007 paper about the most recent and violent Ndyuka antibakuu campaign (Thoden van Velzen \& Van Wetering forthcoming). In direct emulation of Akalali — the last major Ndyuka antiwitchcraft prophet - and the earlier pan-Ndyuka Gaan Gadu oracle that Akalali had dismantled, the prophet Gáangá sought to refocus ritual control in a new settlement on the Upper Tapanahoni River. Then in his early twenties, Gáangá incited large groups of young Ndyuka to follow bakuu-possessed women in violently confronting prosperous elders and traditional authorities they accused of afflicting them with bakuu from the city. The accused were beaten, forced to drink a purging potion, and had their property seized or destroyed before the movement was ended by Gáangás incarceration in a state penitentiary. Unlike earlier attempts to purify witchcraft, Gáangá's youthful "foot soldiers" actively attacked the underpinnings of traditional Ndyuka gerontocracy and subjected even the most respectable elders to Gáangá's youthful judgments.

For Thoden van Velzen and Van Wetering, however subversive or revolutionary, the bakuu targeted by Gáangá still represent an attempt to harness "canonical" Ndyuka social imaginary to create new power relations from sweeping economic change (Van Wetering 1992; Thoden van Velzen \& Van Wetering 2004:279-80). In conjunction with mass Ndyuka migration to Paramaribo, intensified dependence on cash from gold mining has created pronounced generational inequality. Young men toil on ancestral territory to produce wealth for absentee elders who control access to mineral rights and the commodities they import from the city. Gáangás assertion that the prosperity of elders is in fact gained from bakuu in exchange for the lives of their junior kin thus made immediate, explosive sense. In this way, Ndyuka descriptions of bakuu act to symbolically condense social tensions that arise from contests over the control of material wealth and moral power. If Ndyuka describe bakuu as wooden, this objectifies the alienation of market relations. If bakuu are imagined as exclusively male, this alludes to the wealth of the young men whose control of river transport during the nineteenth-century gold rush threatened Ndyuka gerontocracy (Thoden van Velzen 1990:85). If bakuu possession is exclusive 
to female mediums, this condenses Ndyuka stereotypes about the aggressive insatiability of the dependent women who remain in the ancestral villages while men seek profit on the coast. ${ }^{13}$

Following Taussig (1980), Thoden van Velzen calls bakuu a "social fetish." Wishing to remove the "stigma of irrationality" from such symbols, he treats bakuu as accurate, yet unconscious, assessments of capitalism. As metaphors, bakuu go beyond simple explanations of competing social classes to account for the ethical complexity of Ndyuka political economy. Unlike the Bolivian and Colombian devil pacts examined by Taussig, neophyte capitalist Ndyuka appear more readily seduced by the allure of capitalist goods and modes of production. For all these authors though, fetishes such as bakuu act as symbols whose very deceptiveness reveals peasant and Maroon societies as "zones of compromise" where the conflicts of wealth and poverty, abundance and violence that capitalism creates must be negotiated in terms of existent moral orders.

\section{Demons in the Mirror}

Two points stand out about the bakru's ever-changing character: first, its intimate connection to money, and second, with frequently inculpating racial and ethnic stereotypes. Because both money and race emerge out of the fundamental entanglement of capitalism and colonialism, we will next analyze how spirits like baccoo mediate this influence in present-day Guianese lives. Before

13 Thoden van Velzen 1990:89. Vernon (1985:16) highlights the fact that, among Ndyuka, men and women describe bakuu differently. This adds a further level of controversy and complexity regarding bakru. While men comprise a majority of those currently accused of being bakuu owners and are also the main specialists in exorcizing them, bakulu predominantly communicate their anger by possessing women. In recent years, reports of baccoo (or legions of them) possessing at once dozens of young high school girls are becoming more common, both in traditional Maroon areas and in French Guiana. As one of our anonymous reviewers put it, "based on the changing situation of Maroon women, the incarnating of the bakuu being ever their incarnation of victimhood." This suggests further work that should take into account the gendered division of labor, of economic consumption, and of relationships with spiritual entities - men and women in the Guianas tend to relate differently to money and to diverse forms of possessing spirits, and therefore to baccoo. We should also highlight that, the three of us being men, in all our fieldwork, many of our primary interlocutors were also men; however biased, the opinions presented in this article are not exclusively male. 
returning to the particulars of Surinamese and Guyanese bakrus, we review the problem of bakuu mediation through influential discussions of capitalism and colonialism in the work of Michael Taussig and Brackette Williams.

In Shamanism, Colonialism, and the Wild Man, Taussig analyzes myths of Spanish conquest, the violence of early twentieth-century rubber tapping, and yagé (ayahuasca) therapeutic rituals to explore the interrelated social power of images of terror, magic, death and healing in the Colombian Putumayo region. In this work, the efficient Marxist division of ideology and reality Taussig maintained in his earlier work on diabolical pacts as peasant critiques of capitalism gives way to the magically refracted simulacra of infinite mimesis (Taussig 1980).

Central to our argument is Taussig's description of the ways in which the politically powerful consistently impute demonic magic to the lower classes and racial others. This results in a particularly (but not uniquely) Putumayan racism sustained by an ambiguous "cult of the primitive" and the synergy established "between rulers and those who may sustain them magically as well as through more material labor" (Taussig 1987:215). This dependence is mutual: conquerors imitate "primitive" magic in order to appropriate it to their own categories of control, while the conquered mimic the military and economic elite in an attempt to appropriate the coercive power of the state. Taussig argues that this process, "implicitly understands that folding the underworld of the conquering society into the culture of the conquered not as an organic synthesis or 'syncretism' of the three great streams of New World historyAfrican, Christian, and Indian-but as a chamber of mirrors reflecting each stream's perception of the other" (Taussig 1987:218).

These ideas are further developed in Mimesis and Alterity, where Taussig demonstrates that the chamber of mirrors metaphor is not only a Putumayan way of representing social power, but his own preferred mode of describing the world he constructs ethnographically (Taussig 1993:59-69, 239-49). Taussig's insight derives from giving equal credence to "historical" narratives of colonial conquest and Amerindian and proletarian myths, magic, and healing. For him, all these elements are refractions of the same culture of terror in which the selfunderstandings of the dominant and dominated alike unfold against a shared history of unrelenting violence.

Taussig's concern with mirrored metaphors and refracted realities is also found in Williams's explanations of the postcolonial contradictions of Guyanese nation building. According to Williams, race, class, ethnicity, and culture are inextricably fused in the historical development of the "particular ideological fields" that instituted Anglo-European hegemony in Guyana. After independence, these discourses took on "phantasmagoric" qualities, as control over the 
racial hierarchy became the subject of violent political struggle. ${ }^{14}$ For Williams, understanding how Guyanese people construct symbols of ethnicity to stereotype individuals requires detailed examination of Guyana's social and economic history (see also Williams 1990). In present-day Guyana, Williams shows, interethnic symbols rooted in the colonial past work as a "fractured mirror" that refracts competing claims of ethnic superiority (Williams 1991:243). Guyanese attempts to exorcize the "ghost of colonialism" have inadvertently produced newly volatile ethnic hierarchies. In this way, "fragments of colonialism" haunt Guyanese lives as a ghostly "ever-present presence" (Williams 1991:234).

The mirror metaphor is one of the most widely used among the many visual tropes in the epistemology of representation. While ideology is often described as a lens affecting how the world is seen through cultural and social categories that filter or distort reality, perhaps unavoidably (Asad 1979:621), the figure of the mirror develops a symbolic understanding of the sign as necessarily reflecting what it stands for mechanistically, as an inverted reality on a flattened surface. This reflection may be accurate, but lacks significant dimensions that purportedly might be uncovered by critical, philosophical or scientific analysis. How Taussig and Williams employ the mirror metaphor therefore encapsulates assumptions central to both of their theoretical positions. The particular insight of the mirror metaphor in their work results from the multiplicity of the resulting reflections. Rather than the simple reciprocal reflection of the bathroom mirror, interethnic symbols, ghosts of cultural hegemony, cults of the primitive, or peasant pacts with the devil, are multilayered and often deceptive reflections of the fractured mirror or chamber of mirrors built by colonial capitalism. As images of something else, these reflections are not necessarily more real than the complex images they reflect and refract, but are presented as more accurate explanations of the exploitation Colombian peasants or Guyanese plantation laborers endure. In the end, Taussig and Williams equally suggest that the social contexts they describe are really haunted, but by power relations, not demons and ghosts.

In this way, Taussig and Williams epitomize canonical elements of symbolic anthropology's deflationary theories of representation. Though foregoing the positivist assurances of earlier functionalist paradigms, Taussig and Williams continue to defend the ultimate determination of others' lived realities by their theories about the ultimate structures of hegemonic power. There might not

14 Williams 1991:33. The author stresses that class, race, and ethnicity by themselves are not the object of Stains on My Name, War in My Veins. The book is an investigation on the mutability of ideological structures of domination built from these distinctions. 
be, as we think Taussig might argue, a final reality outside of the deflecting play of signs but, on the scales of explanatory power and social consequence, the political economy clearly accounts for more than magic and spirits in understanding the lives of others.

\section{The Flow of Money and Stereotypes}

Evidence from the ethnographic record and from our own fieldwork shows that bakuu connect money to ethnic and racial stereotypes. Though we recognize the considerable explanatory virtues of the complex symbolic analyses reviewed in the previous section, our own research leads us to propose that spirits are not reducible to second-order mystifications of colonialism and capitalism. We therefore conclude that bakulu are better understood as commenting on the historically contingent socioeconomic conditions in which they exist rather than as symbolic comments about socioeconomic violence and ethnic tensions. They speak.

Bakuu do communicate a lot about stereotypes. ${ }^{15}$ It can even be argued that they can serve as a surface on which people project the social prejudices and crushing anxieties created by money or its absence. However, as with all forms of spirit, any confrontation with bakulu equally involves doubt. These doubts are a potent element of these entities' magical power and a pervasive constraint on the people and techniques that mediate their existence in the world. The moral taint that comes with any association with baccoo makes assertions of first-hand knowledge about them highly suspect. Everyone knows that these spirits exist, but people are uneasy about claims to definitive knowledge that might imply close personal association. This creates an epistemic gap that people fill by relying on ethnic stereotypes and other assumptions derived from everyday experience in an ethnically divided society. In papering over holes in knowledge of others, discursive objects such as racial caricatures become vital aids in rhetorically fixing how different Guianese people define the nature of humans, spirits, and the workings of political power and the economy.

15 Stereotype is a key concept in the theories of Drummond (1980) and Williams (1991) about ethnic relations in Guyana. What we retain from Drummond and Williams is not so much the pervasiveness of ethnicity, but instead that the analysis of stereotypes cannot ignore how these are negotiated in everyday interactions, in which the mutability of stereotypes not only modifies racism, but also other forms of evaluating the actions of persons identified, at some level, with an ethnic identity. 
The long shadow cast by inherited colonial racial categories in the Guianas ensures that, even when living in close residential proximity to one another, most ethnic communities continue to inhabit distinct social worlds. While people know one another from school and on the street, as with hidden baccoo, the private realities of the members of other ethnic and racial groups remain significantly concealed behind closed doors. Ethnic and racial stereotypes derived from the colonial past bridge these divides, providing an armature on which racial knowledge is formed from fragments of conjecture and speculation.

Such concurrent yet dissonant interpretations of bakulu might well be a case of what Williams calls "horizontal racism encapsulated by vertical racism" where, unable to enforce a single hierarchy of racial superiority, antagonistic racial groups struggle over the values provided by the "ghostly constraints of hegemonic domination" (Williams 1991:159, 257). Thus, however incongruous, the essentially alien ethnic and racial character of bakru ensures that knowledge about them will remain compellingly incomplete. Surinamese and Guyanese of all ethnicities address lacunae in their knowledge of racial others through fragmentary knowledge about money and magic. The mysteries of wealth simultaneously explain, and are explained by what remains correspondingly outside certainty about both spirits and ethnic others (cf. Bubandt 2014). Accordingly, the social effectiveness of bakuu stems from their ability to expose supposedly intrinsic characteristics such as greed, jealousy, and vindictiveness that are otherwise beyond definitive demonstration.

As mentioned earlier, members of other Surinamese ethnic groups stereotype Maroons as violent and primitive, simultaneously devious masters of obia and dumb yokels. If Suriname were this article's exclusive concern, it would not be difficult to argue that, even if Hindustanis fall short of hegemony, they do occupy a more influential position in the country's ethnopolitical hierarchy than Maroons. This relatively greater status should provide more discursive control over the imposition of stereotypes on less influential populations. Our discussion cannot be so constrained, however. Bakru trespass national borders; their range over all the Guianas juxtaposes local racial and ethnic stereotypes with national ones. Similarly, different British and Dutch colonial histories of Guyana and Suriname trouble any uniform account of European domination and racism. ${ }^{16}$ Unlike Taussig's Colombian example, conflicting Maroon and

16 Guyana was composed of three Dutch colonies (Demerara, Berbice, and Essequibo) until it was seized by the British in 1803 , and Suriname was a British colony from 165 o to 1667 . This is not to be ignored, but establishing the influence of Dutch colonial culture in Guyana and of British colonial culture in Suriname is beyond the scope of this article. 
South Asian versions of baccoo are interesting because they cannot be limited to any single asymmetric attribution of racialized magical powers. In this instance, two oppressed peoples almost symmetrically accuse each other of inherently sorcerous impulses that place them beyond the bounds of social assimilation.

Maroon stereotypes about people of South Asian descent (akulis/kulis) revolve around wealth and bigotry. There are plenty of poor Hindustani people in Suriname, just as there are rich Maroons; members of both ethnicities inhabit the same neighborhoods and squatter settlements in and around Paramaribo. Still, colonial policies that gave Hindustanis and other indentured Asian workers land grants to establish themselves as independent peasants and shopkeepers did create persistent inequality (Hoefte 1998). Maroons see Hindustanis as selfish and prejudiced, driven by an insatiable desire for economic advantage, a stereotype that is furthered by conflicting Maroon and South Asian marriage strategies. While many Maroons are explicit that the threat of lineally inherited avenging spirits valorizes seeking reproductive partners beyond their lineage, a preference for exogamy that can be inferred to normalize some interethnic relations, South Asians, whether Hindu or Muslim, prize ethnic endogamy. ${ }^{17}$ Though there are, as always, many exceptions, Maroons remain the single most stigmatized ethnic other for South Asians; the one Indo-Guyanese Muslim man Stuart knew who was married to a Maroon woman was the object of pity and contempt from Surinamese Hindustanis.

It is telling that, other than bakulu, Maroons do not associate South Asians with efficacious magical practices like their own obiya. ${ }^{18}$ Stuart's Maroon friends routinely saw public images of Hindu deities as living bakuu that would afflict anyone who came in contact with them. This limited ritual range is fully in keeping with Maroon stereotypes of South Asians as primarily motivated by antisocial greed and a desire to usurp the land from its rightful AfroSurinamese owners. In Botopasi, Saamaka routinely explained to Rogério that "black people" (nenge) and Hindustanis are constitutionally unable to live with one another, offering the persistent racial violence of postindependence Guyana and Trinidad as pointed illustrations. ${ }^{19}$

17 Many Saamaka feel that akulis do not like to associate with Maroons, and they severely criticize Hindustani endogamy. On the other hand, Hindustanis (such as doctors and teachers) that lived in Botopasi always seemed to be welcomed-overarching prejudices often fall to the background once personal relationships are established.

19 This is a common-sense view in Suriname: Guyana and Trinidad are taken as counterex- 
The literature on Guyana attests to similar views that racial tensions between Indians and Africans (Indo- and Afro-Guyanese) are unavoidable. ${ }^{20}$ Guyanese stereotypes center on the lazy, violent, bored "African" and the industrious, clannish, and selfish "East Indian." These stereotypes are importantly tied to sorcery accusations. Despite the everyday abundance of Guyanese stereotypes that supposedly explain every facet of social life, obeah is not the exclusive attribute of any specific ethnicity, and there are numerous obeah practitioners of both Indian and African descent. At the same time, Guyanese lament the characterization - common in Suriname and Trinidad - that their country is a hotbed of "black magic." Guyanese contend that Maroons are the real masters of black magic. This sentiment is particularly pronounced among devotees of the Hindu goddess Kali whose rituals involving spirit possession and animal sacrifice are routinely stigmatized as witchcraft. "Kali is not obeah," Kali devotees regularly assert, "obeah is a Djuka thing."

Obeah seems to dominate how Guyanese imagine Surinamese Maroons. This stereotype is also encountered by Maroon migrants in urban Suriname, as Hindustanis also assert that bakru are "a Maroon thing" that come "from the jungle." The main difference is that, at least for Guyanese who remain in Guyana, the absence of social contact with living Maroons permits their use as monstrous caricatures of primitive difference. On the whole, the Guyanese we know tended to think of obeah as essentially malevolent. Similarly, baccoo are regarded as the result of Maroon peoples being primordially evil. As in Guyana, in Suriname obia is often-but not exclusively—associated with Maroons. Unlike in the Anglophone Caribbean where obeah has become a term for deriding the ritual practices of the lower classes and racialized others, ${ }^{21}$ obia retains greater ethical ambiguity, simultaneously a source of pride for many Maroon and Creole Afro-Surinamese, and a label for malicious magic and superstition. Further, in keeping with stereotypes of Maroons as ignorant bumpkins, even the idea that Maroons possess superior magic is sometimes rejected by non-Maroon Afro-Surinamese and Hindustanis. On the other hand, some Maroons are happy to cultivate other ethnic groups' fear of obia. Fear is good, they argue, because it instills respect for Maroons.

Analyzing Guyanese and Surinamese Maroon descriptions of bakru in tandem elucidates how racial stereotypes and witchcraft accusations are mutually reinforced. The common refusal of South Asians and Maroons to consider

amples of "failed" plural societies with pervasive racial violence, while in Suriname these tensions seem to be under control due to a more balanced distribution of power.

$20 \quad$ Drummond 1980, Jayawardena 1963, Smith 1962, Trotz \& Peake 1999, and Williams 1991.

21 Bilby \& Handler 2004, Crosson 2015, Paton 2015, Paton \& Forde 2012, and Rocklin 2015. 
bakuu indigenous to their own ethnic groups reveals how people "fill in the blanks" about largely unknown occult spirits with features they believe these spirits share with somewhat distant, quasi-unknown ethnic and national others. Stereotypes, detrimental as they are, comprise powerful modes of knowledge. Being alien spirits, baccoo have to be made, captured, or bought from outsiders, whose differences provoke debate. Because South Asians and Maroons occupy differently inassimilable extremes on Suriname's ethnic spectrum, they act as perfect foils for one another's imagination of threatening ethnic difference. These perceptions expand when introduced to Guyana, where Maroons represent a further threshold of menacing otherness that embed bakulu within reciprocally reinforcing "registers of negativity" (Palmié 2012:317).

Negative stereotypes aside, South Asians and Maroons are connected by the common perception that Europeans tricked their ancestors into indenture or slavery. ${ }^{22}$ The discourse of trickery reveals an ambiguous amalgam of outrage and acceptance that mingles indignant condemnation of European exploitation with, at least partial, resignation to the racialized ideologies Europeans used to justify the violence of the plantation system. This tense consensus is similar to ideas about bakuu in important respects. Critically, bakulu are foreign contagions introduced into what are described as previously more homogeneous moral communities by the ethical failures of their own members. Just as targets of fraud are routinely judged complicit in their own victimization, buyers of baccoo are seen as succumbing to destructive tendencies within their own ethnic group that are nonetheless held to be better epitomized by ethnic others. Any outrage over the corruption bakuu introduce is thus tinged with an angry acceptance of the ease with which the collective moral values that underwrite group solidarity are compromised by ultimately corrosive promises of wealth from beyond the community.

Bakru also express the violent complexities of the colonial past in another way. As noted by a number of scholars of the Afro-Atlantic world (Johnson 2014; Palmié 2002; Richman 2005), ideologies that emphasize the inevitably destructive excess of commercially transacted, often enslaved, spirits are similar to the self-negating excess of the classical Hegelian master-slave dialectic. Attempts to profit from domination lead to being dominated by those whose very sub-

22 It is a common perception among Indo-Guyanese that Europeans tricked their ancestors in India into indenture labor in the Americas with lies about the fortunes awaiting them (Mello 2014:82). Maroons tell a similar story about their forebears: white people threw a party on a ship and lured Africans with music, food, and drink. The ship set sail from the coast of Africa before the victims could realize that they were actually being enslaved (Pires 2015:363, n. 242). 
ordination confers mastery. A person who possesses a baccoo is an "owner" completely ruled by his or her "property." In this sense, bakuu impart a pointedly egalitarian lesson. However effective in the short term, illicit attempts to gain unmerited power through wealth inevitably lead to the destruction of the relations that endow moral personhood and ensure social continuity. In consuming the relations that make Guyanese villagers or Maroon lineage members ethical agents of transhistorical corporate identities, bakulu eviscerate the moral certainties of kinship. As Ndyuka frequently say, bakuu-wielding witches "break the lineage."

Though, following Peter Geschiere (2013) and Nils Bubandt (2014), there is good reason to think that such moral crises are not limited to capitalist "transitions," it is instructive to observe how readily baccoo map on to market relations; to quote Kwon, "the production of mass human suffering and death [are] part of wealth creation in modern economic history" (Kwon 2008:148). In other words, what remains constant across all these paradigms of bewitching spirits is the equation of wealth, domination, and deceit.

This equation allows us to shift our attention to the relationship between money, value, and morality as mediated through notions of material (and spirit) possession. With Paul Johnson, we contend that the history of slavery (and indenture) continues to fuse "tropes of spiritual possession, material possessions, and possessable persons" into contemporary practices (Johnson 2014:6-7). At the same time, because spirit power stems from spirits' transgressive unpredictability, the empirical threads that tie together servitude, sovereignty, and collusion require ethnographic investigation to be effectively understood (Espírito Santo \& Blanes 2014; Johnson 2014; Lambek 2014).

But if money — or rather the relations money mediates-is central to understanding bakru, we must take seriously what kinds of social relations and practices money creates. This is most apparent as regards consumption. Bakulu are voracious. Though we have given multiple examples of interpretations about their eating habits, what remains consistent across accounts is the escalating excess of baccoo's appetites. A bakuu's greed will always outstrip an owner's ability to satisfy it. People in the Guianas often describe money also as compelling greed, causing it to eat away at what would otherwise be relations of trust. Money begets the desire for more money. Through the creation of increasing, endless desire, both bakru and money threaten dependable social relations; this explains why both rich people and baccoo owners are regarded as social outcasts. In this sense, both money and bakulu can be understood as acting as "social acids."

The unpredictable results of dealing with bakuu engage another classic feature of social scientific theories of money: liquidity. Money, classical theory 
tells us, is the most liquid of all assets. Purely convertible, money has been frequently defined as a "universal measure of value" or the "radical leveler." Because money can be exchanged for (almost) anything, each moment of exchange or market fluctuation can potentially transform monetary capital into something else.

Despite their influence, recent scholarship has questioned theories that posit money's unbounded protean power. Even in the contexts of Europe and North America where money is supposedly completely unmarked, it has never achieved complete hegemony over the assessment of value (Zelizer 2011). Bill Maurer (2006), among others, critiques the idea of money as social acid, and ethnographies of Africa (De Witte 2003), Asia (Kwon 2008), and the Caribbean (Neiburg 2016) all demonstrate the important ways money bonds people together. We do not dispute this, especially since our interlocutors regard aspects of monetization such as the remittances from Guyanese migrants that partially sustain many Hindu temples as net positives. However, unlike certain theorists (Bloch \& Parry 1989; Mauer 2006) who have maybe too readily asserted that rhetorics about money's social destructiveness are simply projections of "Western folk theories" onto ethnographic data, we take our informants' ethical ambivalence about money as authoritative. For many in the Guianas, even though they accept money as a necessary evil of the contemporary world, they still think of it "like the devil," which threatens to "break the family." In this work, the "money-as-acid hypothesis" stems from the ethnographic data, and therefore should be taken seriously as an ethnographic theory. ${ }^{23}$

Such attitudes connect bakru, as commodities, to the desires that define commodities more widely, especially luxury goods, the seductive power of which seems to always compel a desire for more. For a person to invest his/her wealth in conspicuous signs of social power is to be dominated by the capricious conventions of fashion and the reactive cruelty of public regard that turns as readily to envy as to admiration. Like cash, luxury cars, or flashy clothes, bakulu are unpredictable, always threatening to transform the value of relations, people, and things. Despite the mercurial capacity of money to transmute into many different things, it is also limited by its material form and political economic change. Colonial and postcolonial Suriname and Guyana have endured similar histories of inflation and devaluation. Though money can theoretically become something else at any moment, as often as not,

23 There are, of course, a rich multiplicity of topics in the anthropology of money which we cannot deal with here (for some interesting approaches, see Akin \& Robbins 1999, Graeber 2001, and Keane 1997). 
Surinamese and Guyanese have seen their attempts to accumulate wealth destroyed overnight by political crises or fluctuations in commodities markets. Though the only reliable means of achieving something like future security, money is unpredictable and evasive. It is never quite what people think it is, and always threatens to turn on those who own it.

In this respect, transformations in descriptions of baccoo between communities index money's mercurial cruelty as much as its caustic effects on noncapitalist forms of solidarity. By pointing out this similarity, we are not arguing that - and this is our main critique of Vernon, Thoden van Velzen and Van Wetering-bakuu "reflect" Guyanese and Suriname anxieties about the dangers of the wealth created by capitalism. Rather, we contend that bakulu are agents of capitalism as surely as is money. Bakru take on the form they do because they can only exist within market relations, and accordingly share the limited qualities imposed by the ways in which capitalist markets attempt to constrain the conduct of sociality. Baccoo are not simply the fantastic shadow of capitalism; they are one more of its active agents, whose presence alters how people understand and evaluate how they should relate to others. In this way, bakuu change money, or at least the ways many people in the Guianas think about and relate to wealth, as shown in the ethnographic episode with which we started this article.

The very existence of bakru changes the meaning of "making a living" (Williams 1991) for many Surinamese and Guyanese. It forces them to deal more attentively with the variability and unexpectedness of currency, which is often synonymous with the discernment of occult power, or, more specifically, managing the social costs resulting from baccoo. This helps explain why people from across the Guianas routinely agree that magic explains financial inequalities, whether it is the wealth of celebrities such as Bill Gates or Lil' Wayne, or local businessmen and politicians. Baccoo cost money and are thus able to create prosperity-nobody would want to buy one if they were not seen as effective. As mediators, bakuu importantly condition the ethical implications and social risks of the monetized and racialized contradictions that define the postcolonial Guianas.

\section{Conclusion}

Baccoo could be regarded as simple reflections of sociocultural conditions of resentment and exploitation. Against this approach, we contend that the effects of bakuu extend directly from the characteristics people ascribe to them as malevolent spirits and perceive in the conflicts and misfortunes they create 
within communities. If we accept people's descriptions and actions as evidence of their reality, differences in Maroon and Indo-Guyanese portrayals of baccoo would indicate different sorts of spirit. Our interlocutors, however, insist that they are describing one and the same spirit, even if they disagree about some of its most salient attributes. Like Rogério's Saamaka friend scoffing at the Indo-Guyanese notion that bakulu are fed milk and bananas, in disagreements among the different groups, people hold that accounts of these spirits provided by members of other ethnic groups must be wrong in detail, but not in essence. In this sense, whether called baccoo or bakulu, Maroons and Indo-Guyanese all agree that these terms pick out a species of being whose existence is continuous across contexts. What is true for one person living in a specific village or going to a particular temple may not be so for a neighbor or fellow devotee, but their descriptions share enough ground to know what they disagree about. As we saw from the episode with which we opened - and like money or racemuch of the agreement about bakuu emerges from the inability to contest the evidence that seemingly makes them obvious. Once established, people find that diverse elements of their lives are suddenly entangled with previously unknown objects, the full implications of which are only ever partially discerned, but which still makes sense of what otherwise eludes full comprehension. It is thus not the reality of bakuu that is at question, but how people should respond to the ethical crises, and sometimes very real violence, that their existence provokes.

In this article, we argued that bakulu are, at least by some measure, evidence of historical inequalities, injustices, and stereotypes. However, we also showed the limitations of interpreting bakru as simply reflections of capitalism and colonialism, as if social configurations and domination are a priori more real than spirits. In sum, we do not think that baccoo should be grounded in some other, more ostensibly verifiable level of explanation (Abramson \& Holbraad 2014). For people in the Guianas and elsewhere in the Caribbean, bakuu have concrete existence, anchored in evidence such as disparities of wealth and the misfortunes inequality generates, but also in possession, dreams, magic formulas, and oracles-all of which are often as tangible and influential as political economy is in the daily lives of the many peoples of the Guianas.

In this regard Heonik Kwon provides an important warning about reducing spirits to historical metaphors (Kwon 2008:15-16, 168). Like the ghosts of the Vietnam War, bakru are not simply allegories conjured to explain the meaning of present-day events, but have a concrete historical existence in the places and relations they haunt. However mired in misunderstanding, disagreement, and equivocation, similar histories of domination by shifting regimes of racializing capitalism have created a common Guianese experience of coercion. Whatever 
the details of the final claims different peoples make, this shared history has resulted in a common frame of reference rooted in similar problems.

Bakuu clearly manifest the shared reality afflicted on contemporary Suriname and Guyana by the perduring aftermath of colonial capital. While other otherwise invisible agencies such as Hindu deities or Maroon spirits remain decidedly constrained by the ritual traditions that address and deploy them, bakuu roam widely across multiple cosmological frames. Indeed, for many Hindus and Maroons, the materiality of other traditions such as Hindu statues or Maroon flags are often simply conflated with what they imagine as their ethnic antagonists' natural affinity for bakuu. In this way, like the new forms of inequality and rampant intra- and interethnic suspicions that colonial capital has also bequeathed to the present, bakuu are encountered as a pernicious reality that Maroons and Hindus, Guyanese and Surinamese all feel they have no choice but to confront.

History is inevitably implicated in the construction of a people's present realities; this is especially true for populations such as Maroons and IndoGuyanese who have had to reconstruct their universes in the wake of the traumas of slavery, indenture, and acrimonious struggles for independence. Historicizing, however, does not require that alternative "historical ontologies" (Hacking 2002) be effaced by academically approved archival pasts and paradigms of historical causation (Palmié \& Stewart 2016). If we begin with the bare facts of bakulu, they can help better explain capitalism and colonialism as these actually impact Surinamese and Guyanese lives. In a similarly pragmatic fashion, Philippe Pignarre and Isabelle Stengers (2005) draw on extensive parallels between capitalism and witchcraft to show how techniques for protecting against witchcraft might be analogously employed as defenses against capitalism. Perhaps bakuu, as inhabitants of the social crossroads of money and magic, reveal a related apotropaic awareness among the diverse Guianese populations we have discussed.

In this article, we have explored bakuu and ethnic stereotypes as related mediators of the interpersonal and interethnic knowledge that permit people to use gaps in their familiarity with ethnic others to understand monetized conflicts over inequality within and between communities. When the baccoo speak in the newspapers or through the convulsed bodies of the young women they possess, a multitude of issues from violent crime to kinship and interethnic relations are addressed. In doing so, bakulu modify the ways people understand the workings of money, magic, and race. In this article, we surveyed multiply conflicting conceptions of bakuu. The pervasive doubts and instabilities that demarcate this maze of clashing experiences of money, magic, and race are difficult to resolve. More than misrecognized reflections of capital- 
ism or colonialism, bakuu contribute a distinctive spark to combusting (and sometimes extinguishing) the idiosyncratic tender of Guianese social relations. Personally and politically speaking, we do not have much doubt that capitalism is frequently demonic, or that colonial regimes of white supremacy continue to afflict the world. These are, however, not the only forces crossing borders in the Guianas.

\section{References}

Abramson, Allen \& Martin Holbraad, 2014. Introduction: The Cosmological Frame in Anthropology. In Allen Abramson \& Martin Holbraad (eds.), Framing Cosmologies: The Anthropology of Worlds. Manchester: Manchester University Press, pp. 1-29.

Akin, David, 1996. Local and Foreign Spirits in Kwaio, Solomon Islands. In Jeanette Marie Mageo \& Alan Howard (eds.), Spirits in Culture, History, and Mind. New York: Routledge, pp. 147-72.

Akin, David \& Joel Robbins, 1999. An Introduction to Melanesian Currencies: Agency, Identity, and Social Reproduction. In David Akin \& Joel Robbins (eds.), Money and Modernity: State and Local Currencies in Melanesia. Pittsburgh PA: University of Pittsburgh Press. 1-40.

Asad, Talal, 1979. Anthropology and the Analysis of Ideology. Man New Series 14(4): 6o727 .

Beet, Chris de \& Miriam Sterman, 1981. People in Between: The Matawai Maroons of Suriname. Meppel, the Netherlands: Krips Repro.

Bilby, Kenneth M. \& Jerome S. Handler, 2004. Obeah: Healing and Protection in West Indian Slave Life. The Journal of Caribbean History 38(2):153-83.

Bubandt, Nils, 2014. The Empty Seashell: Witchcraft and Doubt on an Indonesian Island. Ithaca NY: Cornell University Press.

Comaroff, Jean \& John L. Comaroff, 1999. Occult Economies and the Violence of Abstraction: Notes from the South African Postcolony. American Ethnologist 26(2):279303 .

Crosson, J. Brent, 2015. What Obeah Does Do: Healing, Harm, and the Limits of Religion. Journal of Africana Religions 3(2):151-76.

Drummond, Lee, 1980. The Cultural Continuum: A Theory of Intersystems. Man New Series 15:352-74.

Espírito Santo, Diana \& Ruy Blanes, 2014. Introduction: On the Agency of the Intangibles. In Ruy Blanes \& Diana Espírito Santo (eds.), The Social Life of Spirits. Chicago: University of Chicago Press, pp. 1-32.

Geschiere, Peter, 1997. The Modernity of Witchcraft: Politics and the Occult in Postcolonial Africa. Charlottesville: University of Virginia Press. 
Geschiere, Peter, 2013. Witchcraft, Intimacy, and Trust: Africa in Comparison. Chicago: University of Chicago Press.

Gibson, Kean, 2001. Comfa Religion and Creole Language in a Caribbean Community. New York: State University of New York Press.

Givens, Shelby M., 1984. An Ethnographic Study of Social Control and Dispute Settlement Among the Aluku Maroons of French Guiana and Surinam, South America. Ph.D. Dissertation, University of California, Berkeley.

Graeber, David, 2001. Toward an Anthropological Theory of Value: The False Coin of Our Own Dreams. New York: Palgrave.

Green, Edward C., 1974. The Matawai Maroons: An Acculturating Afro-American Society. Ph.D. Dissertation, Catholic University of America, Washington DC.

Green, Edward C., 1978. Winti and Christianity: A Study in Religious Change. Ethnohistory $25(3): 25^{1-76 .}$

Hacking, Ian, 2002. Historical Ontology. Cambridge MA: Harvard University Press.

Herskovits, Melville J. \& Frances Herskovits, 1936. Suriname Folk-lore. New York: Columbia University Press.

Hoefte, Rosemarijn, 1998. In Place of Slavery: A Social History of British Indian and Javanese Laborers in Suriname. Gainesville: University Press of Florida.

Jayawardena, Chandra, 1963. Conflict and Solidarity in a Guianese Plantation. London: Athlone Press.

Johnson, Paul Christopher (ed.), 2014. Spirited Things: The Work of "Possession" in AfroAtlantic Religions. Chicago: University of Chicago Press.

Jolivet, Marie-José, 2013. Modèle occidental et créolisation: L’Exemple de la Guyane. L'Homme 207-8:113-34.

Keane, Webb, 1997. Sings of Recognition: Powers and Hazards of Representation in an Indonesian Society. Berkeley: University of California Press.

Khan, Aisha, 2004. Callaloo Nation: Metaphors of Race and Religious Identity Among South Asians in Trinidad. Durham NC: Duke University Press.

Kuiperbak, Mildred, 1989. Een demon in de stortkoker: Een onderzoeksnotitie uit de Amsterdamse Bijlmermeer. Sociologische Gids 36(3/4):267-86.

Kwon, Heonik, 2008. Ghosts of War in Vietnam. Cambridge: Cambridge University Press. Lambek, Michael, 2014. Afterword: Recognizing and Misrecognizing Spirit Possession. In Paul Christopher Johnson (ed.), Spirited Things: The Work of "Possession" in AfroAtlantic Religions. Chicago: University of Chicago Press, pp. 257-76.

Latour, Bruno, 1993. We Have Never Been Modern. Trans. Catherine Potter. Cambridge MA: Harvard University Press. [Orig. 1991.]

Lenoir, John D., 1973. The Paramacca Maroons: A Study in Religious Acculturation. Ph.D. Dissertation, New School for Social Research, New York.

Lewis, Linden, 199o. Exploring the Folk Culture of Barbados through the Medium of Folk Tale. Caribbean Studies 23(3/4):85-94. 
Lier, W.F. van, 1940. Aanteekeningen over het Geestelijk Leven en de Samenleving der Djoeka's (Aukaner Boschnegers) in Suriname. Bijdragen tot de Taal-, Land- en Volkenkunde 99(1):155-294.

Marx, Karl, 1976. Capital: A Critique of PoliticalEconomy. Volume One. Trans. Ben Fowkes. London: Penguin. [Orig. 1867.]

Maurer, Bill, 20o6. The Anthropology of Money. Annual Review of Anthropology 35:1536.

Mello, Marcelo Moura, 2014. Devoções manifestas: Religião, pureza e cura em um templo Hindu da Deusa Kali-Berbice, Guiana. Ph.D. Dissertation, Universidade Federal do Rio de Janeiro, Rio de Janeiro.

Neiburg, Federico, 2016. A True Coin of Their Dreams: Imaginary Monies in Haiti. Hau 6(1):75-93.

Palmié, Stephan, 2002. Wizards and Scientists. Explorations in Afro-Cuban Modernity and Tradition. Durham NC: Duke University Press.

Palmié, Stephan, 2006. Thinking with Ngangas: Reflections on Embodiment and the Limits of "Objectively Necessary Appearances." Comparative Studies in Society and History 48(4):852-86.

Palmié, Stephan, 2012. Afterword: Other Powers: Tylor's Principle, Father Williams's Temptations, and the Power of Banality. In Diana Paton \& Maarit Forde (eds.), Obeah and Other Powers: The Politics of Caribbean Religion and Healing. Durham NC: Duke University Press, pp. 316-40.

Palmié, Stephan, 2013. The Cooking of History: How Not to Study "Afro-Cuban" Religion. Chicago: University of Chicago Press.

Palmié, Stephan \& Charles Stewart, 2016. Introduction: For an Anthropology of History. Hau 6(1):207-36.

Parris, Jean-Yves, 2011. Interroger les morts: Essai sur la dynamique politique des noirs Marrons Ndjuka du Surinam et de la Guyane. Matoury, Guyana: Ibis Rouge.

Parry, Jonathan \& Maurice Bloch, 1989. Introduction: Money and the Morality of Exchange. In Maurice Bloch \& Jonathan Parry (eds.), Money \& the Morality of Exchange. Cambridge: University of Cambridge Press, pp. 1-32.

Paton, Diana, 2015. The Cultural Politics of Obeah: Religion, Colonialism and Modernity in the Caribbean World. Cambridge: Cambridge University Press.

Paton, Diana \& Maarit Forde (eds.), 2012. Obeah and Other Powers: The Politics of Caribbean Religion and Healing. Durham NC: Duke University Press.

Peake, Linda \& D. Alissa Trotz, 1999. Gender, Ethnicity and Place: Women and Identities in Guyana. London: Routledge.

Pignarre, Philippe \& Isabelle Stengers, 2005. La sorcellerie capitaliste: Pratiques de désenvoûtement. Paris: La Découverte.

Pires, Rogério Brittes W., 2015. A mása gádu kốndë: Morte, espíritos e rituais funerários em uma aldeia Saamaka Cristã. Ph.D. Dissertation, Universidade Federal do Rio de Janeiro, Rio de Janeiro. 
Pires, Rogério Brittes W., 2017. Dinheiro, tecidos, rum e a estética do eclipsamento em Saamaka. Mana: Estudos de Antropologia Social 23(3).

Price, Richard, 1973. Avenging Spirits and the Structure of Saramaka Lineages. Bijdragen tot de Taal-, Land- en Volkenkunde 129(1):86-107.

Price, Richard, 2008. Travels with Tooy: History, Memory and the African American Imagination. Chicago: University of Chicago Press.

Richman, Karen, 2005. Migration and Vodou. Gainesville: University Press of Florida.

Rocklin, Alexander, 2015. Obeah and the Politics of Religion's Making and Unmaking in Colonial Trinidad. Journal of the American Academy of Religion 83(3):697-721.

Simmel, Georg, 2004. The Philosophy of Money. Trans. Tom Bottomore \& David Frisby. London: Routledge. [Orig. 1907.]

Smith, Raymond T., 1962. British Guiana. London: Oxford University Press.

Taussig, Michael T., 1980. The Devil and Commodity Fetishism in South America. Chapel Hill: University of North Carolina Press.

Taussig, Michael T., 1987. Shamanism, Colonialism, and the Wild Man: A Study in Terror and Healing. Chicago: University of Chicago Press.

Taussig, Michael T., 1993. Mimesis and Alterity: A Particular History of the Senses. London: Routledge.

Velzen, H.U.E. Thoden van, 199o. Social Fetishism Among the Surinamese Maroons. Etnofoor 3(1):77-95.

Velzen, H.U.E. Thoden van \& Wilhelmina van Wetering, 2001. Dangerous Creatures and the Enchantment of Modern Life. In Paul Clough \& Jon P. Mitchell (eds.), Powers of Good and Evil: Social Transformation and Popular Belief. Oxford: Berghahn Books, pp. $17-42$.

Velzen, H.U.E. Thoden van \& Wilhelmina van Wetering, 2004. In the Shadow of the Oracle: Religion as Politics in a Suriname Maroon Society. Long Grove IL: Waveland Press.

Velzen, H.U.E. Thoden van \& Wilhelmina van Wetering, forthcoming. A Gleam of Gold and the Smell of Witches. http://www.academia.edu/28003398/A_Gleam_of_Gold _and_the_Smell_of_Witches

Vernon, Diane, 1980. Bakuu: Possessing Spirits of Witchcraft on the Tapanahony. New West Indian Guide 54(1):1-38.

Vernon, Diane, 1985. Money Magic in a Modernizing Maroon Society. Tokyo: ILCAA.

Williams, Brackette F., 199o. Dutchman Ghosts and the History Mystery: Ritual, Colonizer, and Colonized Interpretations of the 1763 Berbice Slave Rebellion. Journal of Historical Sociology 3(2):133-65.

Williams, Brackette F., 1991. Stains on My Name, War in My Veins: Guyana and the Politics of Cultural Struggle. Durham NC: Duke University Press.

Witte, Marleen de, 2003. Money and Death: Funeral Business in Asante, Ghana. Africa 73(4):531-59. 
Wetering, Wilhelmina van, 1992. A Demon in Every Transistor. Etnofoor 5(1/2):109-27. Wooding, Charles J., 1972. The Winti-Cult in the Para-District. Caribbean Studies 12(1): $5^{1-78 .}$

Wooding, Charles J., 1981. Evolving Culture: A Cross-Cultural Study of Suriname, West Africa and the Caribbean. Washington DC: University Press of America.

Zelizer, Viviana A., 2011. Economic Lives: How Culture Shapes the Economy. Princeton NJ: Princeton University Press. 